\title{
SENIOR CITIZENS' LEARNING AND ACTIVITY IN THE LABOUR MARKET
}

\author{
Ausra Rutkiene \\ Silva Lengviniene \\ Vytautas Magnus University, Lithuania
}

\begin{abstract}
The data provided by Eurostat show that adults who are aged 55 and over participate in education and training about 20 perc. less frequently than the younger ones, who are aged from 18 to 54. Such results are caused by imperfection of adult education, employer attitude and other reasons. Research studies performed in 2004-2006 revealed the problems which arise both for those adults who intend to study and also to educational institutions. Question of the research - which factors cause senior citizens' motivation to learn aiming at staying active in the labour market? Survey was performed in 2016, 453 respondents participated in the research. The findings show that well-being, economical factors and learning play a decisive role in senior citizens' staying active in the labour market as well as previous education and place of residence.
\end{abstract}

Keywords: labour market, learning, senior citizens.

\section{Introduction}

High standard of living in the Western society has had impact upon the progressive ageing of the population. Better health system policy and social as well as economic development determine longevity. It has been estimated that by 2030 the number of senior age citizens in the United States of America will have increased twice, up to approximately 72 million according data provided by US Department of Health and Human Services. According to the European rural development report (ERD, 2002), prior to 1950 the number of senior age persons (over 65) in all European countries had been over 45 million; however, by 2050 the number of people over 65 in Europe will have reached 173 million. Ageing is one of the challenges to the population, which will have affected one third of the whole European population by 2050. It is a social challenge which is related to lifelong learning (Martorell et al., 2009). Challenges caused by demographic changes have been experienced by the whole world; however, senior age people experience specific challenges in the labour market (Killam et al., 2014), as they often become encounter a complicated situation, i.e. they have accumulated 
experience and knowledge; nevertheless, they often have to endure stereotypes about senior age people.

Lithuanian and foreign scientists (Lunau et al., 2013; Aristovnik and Jaklič, 2013; Brazienè et al., 2014), analyzing factors which determine senior citizens' health and retirement, discuss barriers that senior citizens face with, and their situation in the labour market which guarantees education and training of such age persons as well as their possibilities to stay active and competitive in the labour market. Scientific sources (Adomaitienè et al., 2007) and normative documents emphasise the importance of ageing in Lithuania and stress demographic challenges of ageing in the world and Europe which affect senior citizens' staying active in the labour market and their motivated participation in lifelong learning processes. Senior citizens' motivation to participate in nonformal education, to develop themselves and choose appropriate and accessible learning forms is very important (Liu et al., 2011).

\section{Senior citizens' learning and activity in the labour market}

As shown by the latest Programme for the International Assessment of Adult Competencies research (Bužinskas, 2016), senior citizens' literacy is lower than that of young adults; their level of problem solving with the help of technologies is also low.

According to the data of the Ministry of Education and Science of the LR, in 2011 as compared to 2005 or 2007, the lifelong learning indicators of the Lithuanian population remained low. There are different reasons for this, and some of them are related to cultural, social or economic motives, and their change depends on a number of circumstances which are difficult to predict. On the other hand, participation of the employed persons in non-formal learning is limited to very simple reasons - "limited application of flexible forms of the education and training organisation, various non-formal education services of good quality which are difficult to be accessed by individual efforts, an underdeveloped system of validation and recognition of competencies acquired in non-formal learning" (Neformaliojo suaugusiųjų švietimo plètros 2014-2016 metų veiksmų planas, 2013). A great number of non-formal learning services, particularly those related to the development of special skills, are in fact accessible only to organised groups (trainings are organised for employees of enterprises, and etc.). It is emphasised in the document that the educational services are not equally accessible to all groups of society (Neformaliojo suaugusiujų švietimo plètros 2014-2016 metų veiksmų planas, 2013).

Data of the Lithuanian department of statistics, analyzed in the Non-formal adult education development action plan for 2014-2016, show the findings of the 
research into professional qualification development of the employed persons: "in 2010, planned and totally and partly financed training of employees, aiming at their qualification development, was organised by 6.7 thousand $(52$ perc.) enterprises, i.e. 6 percent more enterprises than in 2005.11 perc. of large, 33 perc. of medium and 52 perc. of small enterprises did not organize training at all, indicating the following reasons: 85 perc. of the enterprises claimed that "qualification of their employees met the needs of the enterprise; 79 perc. stated that the enterprise hired only those employees who already had the necessary qualifications; 68 perc. noted that employee training was related to large expenses" (Nonformal adult education development action plan for 2014-2016, 2013). The fact that employees did not have a possibility to learn due to overload and lack of time was indicated by 39 perc. of the enterprises (Neformaliojo suaugusiujų švietimo plètros 2014-2016 metų veiksmų planas, 2013). It should also be emphasised that very often senior age employees experience discrimination because of their age; a number of authors (Chonody et al., 2014; Ball et al., 2000) who explore this problem state that persons of this age can avoid this kind of discrimination and compete as equals as well as stay active in the labour market only if they consistently develop and participate in adult education processes of various forms. The above discussed aspects presupposed the research problem - which factors cause senior citizens' motivation to learn aiming at staying active in the labour market? Aim of the paper - to identify factors influencing senior citizens' motivation to learn aiming at staying active in the labour market.

Research methods: i) Scientific literature analysis aimed at analyzing senior citizens' learning concept in the context of lifelong learning, the topic of ageing, factors which have impact upon the learning needs and motivation as well as staying active in the labour market. ii) Questionnaire survey (quantitative research) was used to identify the impact of learning upon for senior age persons' staying active in the labour market.

Having performed theoretical analysis, an original quantitative research tool was designed (Lengvinienè, 2016). The quantitative research aimed at revealing the importance of learning as one of the preconditions for senior citizens to stay active in the labour market.

Survey was conducted online in September - October, 2016. 453 respondents participated in the research.

\section{Theoretical background of senior citizens learning and activity in the labour market}

Friebe J. and Schmidt-Hertha B. (2013) assert that adult education can play an important role in the old age, preserving adult's autonomy and enhancing 
his/her social participation in life. Thus, both from personal and societal points of view it is important to foster adult persons' educational activity. Senior citizens' need for learning is related to their perception of life quality (Fig. 1) Depending on the perceived and expected life quality at present or in the future, the person makes a decision to learn; therefore, senior age people who have more experience of successful learning understand relationship between learning and life quality. Senior age people's learning needs are related to motivation to develop, which is caused by internal and external drivers. The scope of adult learning in the country and their learning efficiency, first of all, depend on their motivation to learn; therefore, it is important to assess factors of senior citizen's external and internal motivation to learn. "Motivation is defined by two things: need (an internal motivation aspect) and aim (an external motivation aspect).

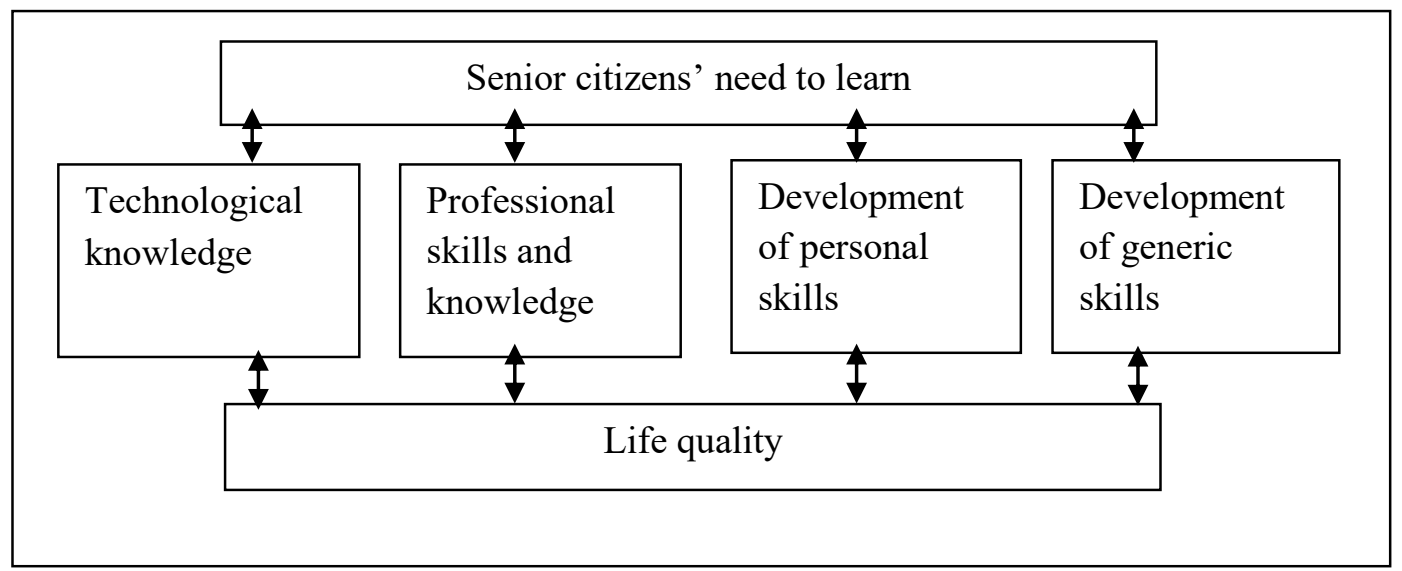

Figure 1 Relationship between senior citizens' learning needs and life quality

Two major factors are distinguished and possible solutions are defined which exert impact upon senior citizens' staying active in the labour market. It should be emphasised that senior citizens' learning peculiarities are based on pragmatic aspects; their learning is oriented to personal responsibility. Thus, in order for an adult to choose a learning offer, it should be attractive and acceptable for people of different status in the society, family status and age, and it should lead to flexible development of competencies.

Learning intensiveness should be tailored to the learner developmental stages and individualised according to his/ her needs. It should be noted that senior citizens' learning as a precondition to stay active in the labour market depends on a number of factors related to person's health, educational background, previous learning experience, financial situation, motivation, active ageing and social participation. Senior citizens, perceiving the importance of life quality, manage to find resources to develop their competencies, which can be successfully used in the professional activity. The importance of the competencies acquired during the 
process of learning accounts for the increased self-confidence and expanded opportunities for employment.

\section{Survey results on senior citizens learning and activity in the labour market}

453 respondents participated in the research, which was organized September - October, 2016 in Lithuania. The youngest participant was aged 55, the oldest -94 . The average age of research respondents was 64.2 . The majority of the respondents - about half of them - were up to 60 years of age, the senior respondents' groups were respectively smaller. There were only 5 per cent of the respondents who were older than 75 .

Among the respondents, 305 were not pensioners yet (67.3 perc.); the rest were already retired; however, a considerable number of the respondents were employed, i.e. 67.6 perc. The person who had least work experience was employed for 10 years, the most - 54 years. The average was 38.3 years. In terms of gender, among all respondents there were 66 perc. of female respondents (299), and 34 percent of male respondents. In terms of place of residence, the largest group of the respondents were from urban places (almost 80 perc.); the rest were from rural regions, i.e. smaller towns or villages. More than half of the respondents (62 perc.) were married, over 10 perc. were widowers or widows and over 16 perc. were divorced. About 10.7 perc. of the respondents had never had a family. In terms of educational background, half of the respondents had higher education (50.3 perc.). A considerable part of them had upper vocational or higher non-university education (37.7 perc.). 12 perc. had vocational, secondary or only basic education.

\section{Table 1 Regression model for staying in the labour market}

\begin{tabular}{|c|c|c|c|c|c|}
\hline \multirow[t]{2}{*}{ Model } & \multicolumn{2}{|c|}{$\begin{array}{c}\text { Nonstandardised } \\
\text { coefficients }\end{array}$} & \multirow{2}{*}{\begin{tabular}{|c|}
$\begin{array}{c}\text { Standardised } \\
\text { coefficients }\end{array}$ \\
Beta \\
\end{tabular}} & \multirow[t]{2}{*}{$\mathrm{t}$} & \multirow[t]{2}{*}{ Sig. } \\
\hline & $\mathrm{B}$ & Std. Error & & & \\
\hline Constant & 10,226 & 0,139 & & 80,846 & 0,000 \\
\hline Well-being & 0,011 & 0,002 & 0,295 & $-60,866$ & 0,000 \\
\hline Health & 0,057 & 0,033 & 0,072 & 10,742 & 0,082 \\
\hline Social factors & 0,020 & 0,033 & 0,026 & 0,596 & 0,552 \\
\hline $\begin{array}{l}\text { Personal } \\
\text { factors }\end{array}$ & $-0,002$ & 0,031 & $-0,002$ & $-0,056$ & 0,955 \\
\hline $\begin{array}{l}\text { Economic } \\
\text { factors }\end{array}$ & 0,290 & 0,044 & 0,310 & 60,512 & 0,000 \\
\hline Competencies & $-0,019$ & 0,045 & $-0,021$ & $-0,425$ & 0,671 \\
\hline Learning & 0,134 & 0,029 & 0,189 & 40,621 & 0,000 \\
\hline
\end{tabular}

Rsquare $=0,270, F=24,869, p=0,000$ 
Ausra Rutkiene, Silva Lengviniene. Senior Citizens' Learning and Activity in the Labour Market

Regression analysis was applied for calculation.

In terms of importance, the most important is the economic factor, and learning is the least important, however, a significant factor. Well-being is significant factor as well (see Table 1, Figure 2).

Estimations show that health, social, personal factors, and professional competencies do not have significance for staying active in the labour market.

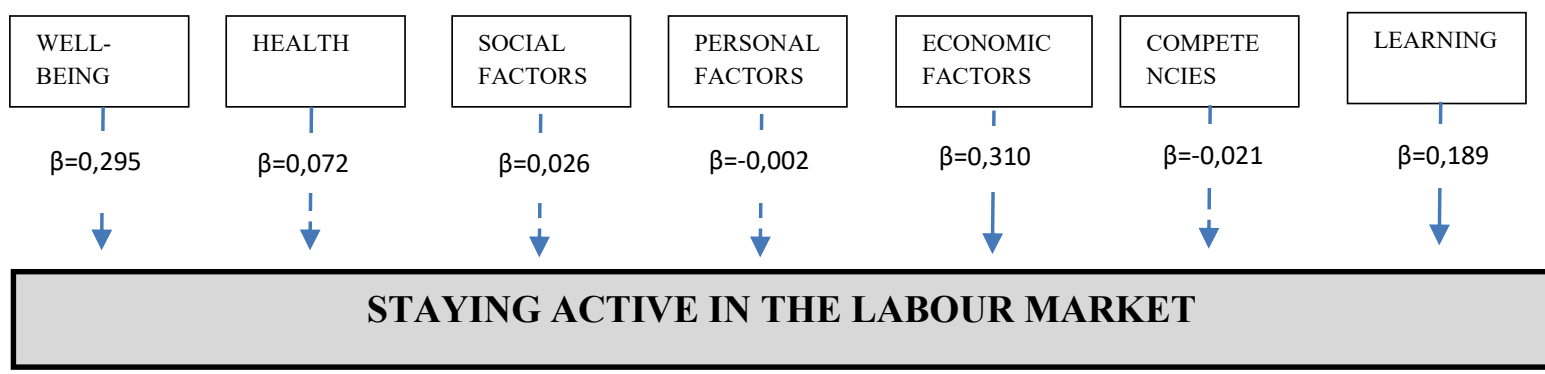

Figure 2 Model of staying active in the labour market (based on Table 1)

Having introduced socio-demographic data into the model, the research results showed that apart from economic factors, well-being and learning, place of residence, educational background and marital status are also significant for staying active in the labour market (see Table 2, Figure 3). Citizens in big cities are more active in labour market as well as married people.

Table 2 Regression model for staying in the labour market with demographic factors

\begin{tabular}{|l|r|r|r|r|r|}
\hline \multirow{2}{*}{ Model } & \multicolumn{2}{|c|}{$\begin{array}{c}\text { Nonstandardised } \\
\text { coefficients }\end{array}$} & $\begin{array}{l}\text { Standardised } \\
\text { coefficients }\end{array}$ & \multirow{2}{*}{$\mathrm{t}$} & \multirow{2}{*}{ Sig. } \\
\cline { 2 - 4 } & \multicolumn{1}{|c|}{$\mathrm{B}$} & Std. Error & \multicolumn{1}{c|}{ Beta } & & \\
\hline Constant & 1,242 & 0,166 & & 7,465 & 0,000 \\
Well-being & $-0,008$ & 0,002 & 0,227 & $-4,989$ & 0,000 \\
Health & 0,054 & 0,033 & 0,068 & 1,657 & 0,098 \\
Social factors & 0,044 & 0,033 & 0,058 & 1,338 & 0,182 \\
Personal factors & 0,024 & 0,031 & 0,034 & 0,777 & 0,438 \\
Economic factors & 0,257 & 0,044 & 0,275 & 5,811 & 0,000 \\
Competencies & $-0,052$ & 0,046 & $-0,058$ & $-1,143$ & 0,253 \\
Learning & 0,121 & 0,028 & 0,170 & 4,243 & 0,000 \\
Age & 0,021 & 0,013 & 0,073 & 1,679 & 0,094 \\
Place of residence & $-0,082$ & 0,035 & 0,100 & $-2,331$ & 0,020 \\
Education & 0,044 & 0,014 & 0,138 & 3,106 & 0,002 \\
Marital status & $-0,036$ & 0,016 & 0,089 & $-2,190$ & 0,029 \\
Gender & $-0,018$ & 0,031 & $-0,024$ & $-0,568$ & 0,570 \\
\hline
\end{tabular}

Rsquare $=0,307, F=17,710, p=0,000$ 
Gender and age appeared to be not so significant, while analyzing senior citizens' staying active in the labour market.

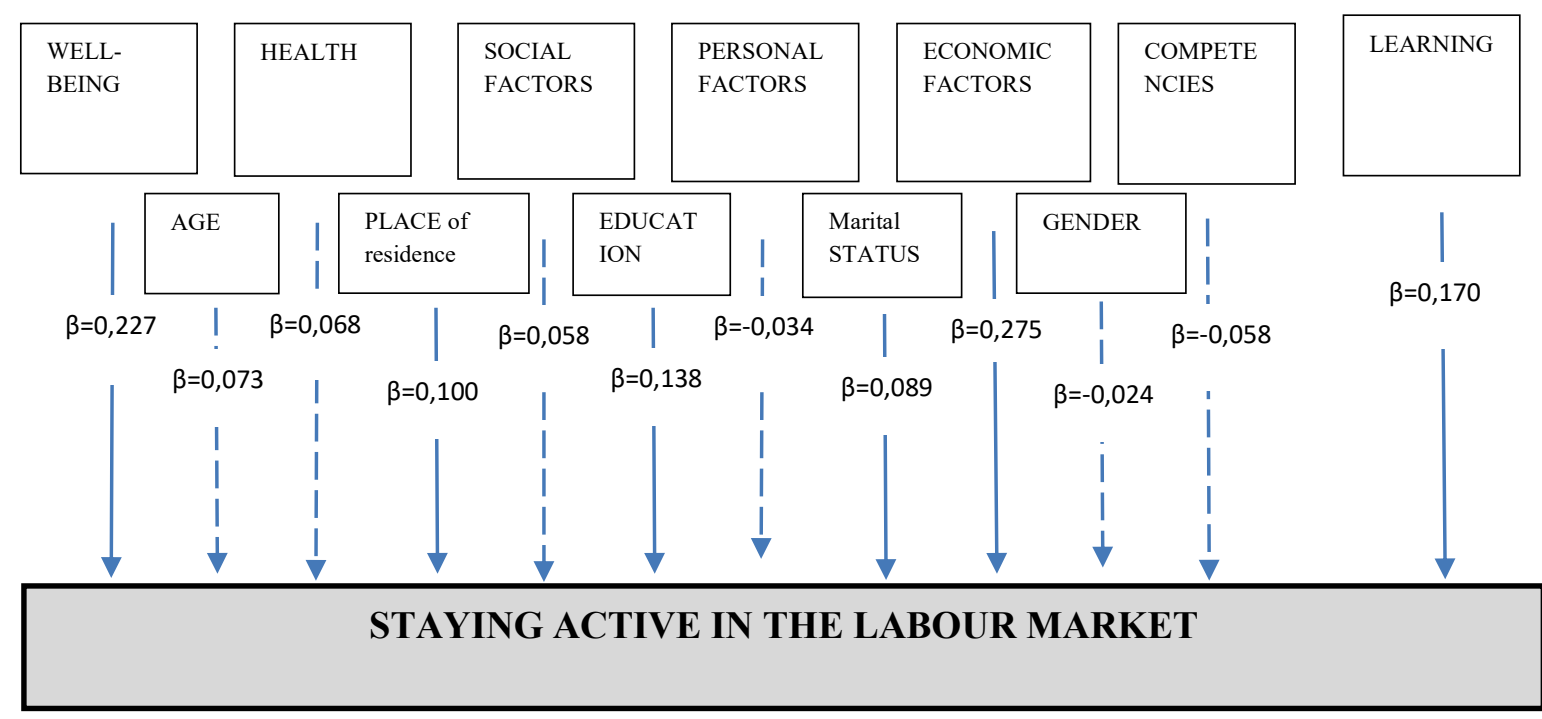

Figure 3 Model of staying active in the labour market with demographic factors (based on Table 2)

Summarising it is possible to state that learning is important, and it most strongly affects on activeness in the labour market as well as senior citizens' health, assessment of well-being and economic factors. Competencies, social and personal factors have no essential importance upon senior citizens' staying active in the labour market. It is interesting to note that if learning is taken as an equal factor, health is not important for staying active in the labour market.

\section{Discussion and Conculsions}

The results of quantitative research show that senior citizens have extensive professional experience and the majority of them are fully employable (88 perc.); however, about one third of them feel/felt discrimination due to their age. The previously performed research indicated that $84 \%$ of persons aged 60 and older mentioned cases when they were sneered at in the workplace, on physical health, for instance, jokes were told about senior people and disrespect showed. Research by R. Brazienè and I. Mikutavičienè (2015) also confirm that senior age becomes a problem in the context of social inclusion (self-involvement) in the labour market due to age discrimination, senior citizens' health problems or lack of necessary and modern skills. The prevailing stereotype that senior age employees have poor health was partly confirmed by the qualitative research findings.

The qualitative research findings confirm one more aspect, revealed by the theoretical analysis regarding senior age persons: possibility and encouragement 
to participate in trainings allows them to feel valued and needed (Innovative learning measures for older workers, 2008).

Even 81.5 perc. of the respondents expressed their intention to learn. This number is higher than that received in previous research (as well as ability to use computers). This notwithstanding, the stereotypical thinking was still proved to be right and confirmed by research that with age the people's health state usually deteriorates and their physical capacity decreases, their short-term and long-term memory important for the acquisition of new knowledge weakens, their ability to concentrate becomes worse (Charness \& Czaja, 2006).

Learning indicators among the senior citizens are not very high: during the period of research 29.8 perc. of the respondents were learning; during the last three years - 55 perc. M. Gosling (2011) states that for senior age employees it is important that they have a possibility to independently choose the opportunity to participate in learning, i.e. they should not be forced to learn; nevertheless, they achieve better learning results when they feel certain control and commitment to the training institution and employers. The reasons indicated by the respondents with regard to why they learn were as follows: they want to have more selfconfidence and develop themselves. The aim to deepen their knowledge and develop skills necessary for the current work was indicated as the third priority. R. Manheimer (2008) notes that training programmes for senior age people are based on pragmatic considerations. Investment into their knowledge and skills creates conditions for senior age people to stay active in the labour market. On the other hand, generic abilities are particularly important (Gedvilienè et al., 2015). The research findings revealed that the success of both new and experienced participants of the labour market is in particular determined by various personality features, skills and abilities: ability to adapt to the changing situations, ability to think critically and solve difficulties and problems arising in the work process, ability to lead, being aware of and following the requirements of work ethics, ability to work in teams, and etc.

Senior citizens are sufficiently active in the labour market. The research shows that even after the age of retirement they continue their professional activity. Urban research participants indicated better sense of well-being that rural respondents. It is interesting to note that people of retirement age are more socially active and curious; they value their sense of well-being better.

Health and economic factors also play a decisive role in senior citizens' staying active in the labour market. The importance of personal and social aspects or professionals competencies, which were indicated in the theory sources as important in the senior age while seeking to be active in the labour market, were not confirmed by the empirical research. Self-assessment of sense of well-being and learning directly relate to the staying active in the labour market. 


\section{References}

Active ageing solidarity between generations (2012). A statistical portrait of the European Union, 7.

Adomaitienė, R., Vozbutas, S., Juozulynas, A., Alekna, V., \& Prapiestis, J. (2007). Lietuvos žmonių aktyvaus senèjimo politikos socialinè sistema struktūrinio funkcionalizmo aspektais. Gerontologija, 8 (1), 7-16.

Aristovnik, A. (2013). Job Satisfaction of Older Workers as a Factor of Promoting LabourMarket Participation in the EU: The Case of Sloveni. Revija za Socijalnu Politiku, $20(2), 123-148$.

Ball, K., Misko, J., \& Smith, A. (2000). The Training Needs of Older Workers. http://www.avetra.org.au/abstracts_and_papers_2000/01.pdf .

Brazienè, R., Mikutavičienè, I., Dorelaitienè, A., Žalkauskaitė, U., \& Jurkevičienė, J. (2014). Vyresnio amžiaus žmoniu (socialinès ịtraukties) ì(si)traukimo ị darbo rinka galimybiu tyrimo ataskaita. Vilnius: Lygiu galimybių kontrolieriaus tarnyba.

Brazienè, R., \& Mikutavičienė, I. (2015). Diskriminacijos dẻl amžiaus raiška Lietuvos darbo rinkoje. Filosofija. Sociologija. T. 26. Nr. 2, 87-98.

Bužinskas, G. (2016). PIAAC rezultatai: Lietuva. http://www.kpmpc.lt/kpmpc/wpcontent/uploads/2016/06/G.Buzinskas_PIAAC_06_28.pdf

Charness, N., \& Czaja, J. S. (2006). Older Worker Training: What We Know and Don't Know? Washington: AARP.

Chonody, J. M, Webb, S. N., Ranzijn, R., \& Bryan, J. (2014). Working with Older Adults: Predictors of Attitudes Towards Ageing in Psychology and Social Work Students, Faculty, and Practitioners. Australian Psychologist, Vol. 49 Issue 6, 374-383.

European rural development report (ERD, 2002), http://hdr.undp.org/sites/default/ files/hdr_2003_summary_en.pdf

Friebe, J., \& Schmidt-Hertha, B. (2013). Activities and barriers to education for elderly people. Journal of Contemporary Educational Studies. Sodobna Pedagogika, 64, 10-26.

Gedvilienè, G., Bortkevičienè, V., Tūtlys, V., Vaičiūnienė, V., Stancikas, E., Staniulevičienè, D., Krivickienè, V., Vaitkevičius, R., \& Gedvilas, P. (2015). Suaugusiuju bendruju kompetenciju pletra. Kaunas: Versus aureus.

Gosling, M. (2011). Older Learners in the Workplace: Research report. City \& Guilds Centre for Skills Development. http://www.skillsdevelopment.org/pdf/Older-learners-in-theworkplace-research-report.pdf

Innovative learning measures for older workers. Luxembourg: Office for official publications of the European Communities (2008).

Killam, W., \& Weber, B. (2014). Career Adaptation Wheel to Address Issues Faced by Older Workers. Adultspan Journal, 13, 68-78.

Lengvinienè, S. (2016). Vyresnio amžiaus asmenu mokymasis, siekiant išlikti darbo rinkoje. $\mathrm{PhD}$ dissertation, Kaunas.

Liu, S., Courtenay, B.C., \& Valentine, T. (2011). Managing Older Worker Training: A Literature Review and Conceptual Framework. Educational Gerontology, 37 (12), 10401062.

Lunau, T., Wahrendorf, M., Dragano, N., \& Siegrist, J. (2013). Work stress and depressive symptoms in older employees: impact of national labour and social policines. BMC Public Health., 13, 1-18. 
Ausra Rutkiene, Silva Lengviniene. Senior Citizens' Learning and Activity in the Labour Market

Martorell, I., Medrano, M., Sole, C., Vila, N., \& Cabeza, L. F. (2009). Inquiry-Based Learning for Older People at a University in Spain. Educational Gerontology. 35 (8), 712-731.

Manheimer, R. J. (2008). Lifelong Learning in Aging Societies. Annual Review of Gerontology \& Geriatrics. 28, 111-127.

Neformaliojo suaugusiuju švietimo plètros 2014-2016 metu veiksmu planas (2013). https://www.e-tar.lt/portal/lt/legalAct/b9068c1052c011e4a698d921e3e46801 